\title{
Czy można odstąpić od usunięcia pachowych węzłów chłonnych przy dodatniej biopsji węzła wartowniczego w raku piersi? Stanowisko „przeciw”
}

\author{
Janusz Jaśkiewicz
}

\section{Can we avoid axillary dissection in positive sentinel node biopsy in breast cancer? Answer: No}

\begin{abstract}
Ocena węzłów chłonnych pachy u chorej na raka piersi (RP) jest jednym z najważniejszych czynników prognostycznych, mającym wpływ na wybór leczenia. Dokładna liczba i szczegółowa ocena stanu węzłów chłonnych ma decydujące znaczenie przy planowaniu uzupełniającej zarówno chemio-, jak i radioterapii. Musimy założyć, że u około 40\% chorych, u których stwierdza się dodatni wartowniczy węzeł chłonny, zmiany przerzutowe mogą wystąpić również w pozostałych węzłach pachy. Termin "dodatni" węzeł chłonny zawiera cztery różne kategorie mikroskopowego rozpoznania pod postacią: izolowanych komórek nowotworowych (ITC — isolated tumour cells), mikroprzerzutów (MI), makroprzerzutów (MA), konglomeratu kilku węzłów chłonnych zajętych przez nowotwór, często naciekający torebkę węzła jak i okołowęzłowe naczynia chłonne i krwionośne. Rozpoznanie ITC w węźle wartowniczym nie stanowi wskazania do usunięcia pachowych węzłów chłonnych, z kolei obecność przerzutów w trzech lub więcej węzłach wartowniczych, a szczególnie z towarzyszącym naciekaniem torebki węzła i/lub naczyń, powinno stanowić wskazanie do usunięcia 2 lub 3 pięter pachy w trybie jednoczasowym lub odroczonym. Decyzja o odstąpieniu od limfadenektomii u chorych na RP z przerzutami do 1-2 węzłów wartowniczych powinna być podjęta wspólnie z chorą w ośrodku referencyjnym, podczas wielodyscyplinarnej konsultacji. Oprócz uzupełniającego leczenia systemowego ta grupa chorych może stanowić wskazania do radioterapii z dodatkowym polem na okolicę pachy.
\end{abstract}

NOWOTWORY Journal of Oncology 2013; 63, 6: 497-500

Słowa kluczowe: rak piersi, węzeł wartowniczy, usunięcie pachowych węzłów chłonnych, izolowane komórki raka, mikroprzerzuty, makroprzerzuty

\section{Wstęp}

Ocena węzłów chłonnych pachy u chorej na raka piersi (RP) jest jednym z najważniejszych czynników prognostycznych decydującym o wyborze leczenia [1, 2]. W badaniu histopatologicznym opis przerzutowych węzłów chłonnych powinien zawierać szczegółowe informacje dotyczące: obecności ognisk mikro- (MI) czy makroprzerzutów (MA), naciekania torebki węzła, zatorów w sąsiadujących naczy- niach chłonnych i krwionośnych. Ważną informacją jest liczba zajętych węzłów w stosunku do pozostałych usuniętych węzłów chłonnych, najlepiej z podziałem na poszczególne piętra pachy. Ustalono również, że preparat po usunięciu pachowych węzłów chłonnych powinien zawierać co najmniej 10 węzłów. Jeśli patolog u chorej na RP ocenia tylko jeden, dwa lub kilka regionalnych (pachowych) węzłów chłonnych, to onkolog planujący leczenie pozbawiony jest

Katedra i Klinika Chirurgii Onkologicznej, Gdański Uniwersytet Medyczny

Wystąpienie podczas I Konferencji Naukowej czasopisma Nowotwory „Debaty onkologiczne” 5-6 kwietnia 2013 roku 
wielu bardzo cennych, wyżej wymienionych informacji. Sytuacja taka nie jest zgodna z jedną z podstawowych zasad dekalogu leczenia nowotworów:„najpierw ustal pełne rozpoznanie ioceń zaawansowanie nowotworu, a potem zaplanuj leczenie". Dokładna liczba i szczegółowa ocena przerzutowych węzłów chłonnych ma decydujące znaczenie przy planowaniu uzupełniającej zarówno chemio- jak i radioterapii. Algorytm postępowania u chorych na RP zakłada, że jeden przerzutowy węzeł chłonny może stanowić podstawę kwalifikacji do leczenia systemowego, a rozpoznanie trzech lub więcej takich węzłów jest wskazaniem do uzupełniającej radioterapii [1-3]. Jeśli do oceny mikroskopowej pobieramy zaledwie jeden węzeł wartowniczy, to pozbawiamy się automatycznie pełnej informacji o pozostałych regionalnych węzłach. Jak potwierdza szereg badań klinicznych, musimy założyć, że u około $40 \%$ chorych, u których stwierdza się dodatni węzeł chłonny wartowniczy, możemy znaleźć zmiany przerzutowe również w pozostałych węzłach pachy [4].W takich sytuacjach klinicznych nasze rozpoznanie jest niepełne, ocena zawansowania mało precyzyjna, i musimy się liczyć z tym, że schemat leczenia może nie być dla chorego optymalny.

\section{Co oznacza termin „dodatni” węzeł chłonny?}

Określenie „dodatni" czy „zajęty" węzeł wartowniczy jest pojęciem mało precyzyjnym i może obejmować szereg różnych sytuacji klinicznych, charakteryzujących się odmiennym rokowaniem i wymagających zastosowania różnych schematów leczenia. Ocena węzłów chłonnych pachy jako „pN1" na podstawie biopsji węzła wartowniczego jest w onkologii wiadomością nieprecyzyjną i stanowi przyczynę wyciągania fałszywych wniosków. Ma to szczególnie miejsce podczas porównania materiałów z różnych ośrodków onkologicznych. Termin „dodatni” czy „zajęty” węzeł chłonny należy rozpatrywać w czterech kategoriach rozpoznania: izolowanych komórek nowotworowych (isolated tumour cells - ITC); mikroprzerzutów (MI), makroprzerzutów (MA), konglomeratu kilku węzłów chłonnych zajętych przez nowotwór, często naciekających torebkę węzła jak i okołowęzłowe naczynia chłonne i krwionośne [2]. Połączenie tych różnie rokujących kategorii nowotworów w jedną wspólną grupę jest daleko idącym uproszczeniem.

\section{Izolowane komórki nowotworowe}

Izolowane komórki nowotworowe to skupiska do 200 komórek nowotworowych, nieprzekraczających średnicy 0,2 mm w pojedynczym węźle chłonnym. ITC w klasyfikacji TNM są określane symbolem pN1 (mi). Należy podkreślić, że zgodnie ze światowymi zaleceniami dotyczącymi diagnostyki i leczenia chorych na RP rozpoznanie ITC w węźle wartowniczym nie powinno mieć wpływu na podejmowanie decyzji terapeutycznych. Dla przykładu: u chorej na RP o zaawansowaniu pT1N1 (mi)M0 nie ma podstaw, w oparciu o tę jedną cechę do zastosowania uzupełniającego leczenia systemowego. Można spotkać w piśmiennictwie pojedyncze doniesienia autorów, którzy z tą tezą się nie zgadzają. Istnieje hipoteza, że ITC mogły zostać sztucznie „wtłoczone” do węzłów chłonnych podczas biopsji gruboigłowej i/lub mamotomicznej, i nie mają one wpływu na przebieg choroby nowotworowej [5-7].

\section{Mikroprzerzuty}

Mikroprzerzuty to ogniska nowotworu w węźle chłonnym o średnicy od 0,2 $\mathrm{mm}$ do $2 \mathrm{~mm}$. Mogą być pojedyncze lub mnogie. MI w klasyfikacji TNM są określane symbolem pN1(mi). Wartość rokownicza MI jest różnie oceniana przez poszczególnych autorów. Milgrom i wsp. uważają, że nie mają one wpływu zarówno na przeżycia odległe (overall survival — OS), jak i na czas bez objawów choroby (disease free survival — DFS) [8]. Z kolei Pepels i wsp. uważają, że MI mają wpływ na wystąpienie wznów miejscowych [9].

\section{Makroprzerzuty}

Makroprzerzuty to skupiska nowotworów o średnicy co najmniej $2 \mathrm{~mm}$. Mogą być jedno lub wieloogniskowe. Są one oznaczane symbolem pN1 według klasyfikacji TNM. O ile w przypadku ITC i/lub Ml istnieją rozbieżności, czy możemy je uznać za przerzutowe węzły chłonne, to w przypadku MA panuje zgoda: są to "dodatnie" węzły chłonne i upoważniają do podejmowania decyzji terapeutycznych. Większość standardów europejskich i amerykańskich jednoznacznie stwierdza, że rutynowo do oceny MA w węzłach chłonnych należy stosować tradycyjną metodę barwnikową, opartą na hematoksylinie i eozynie (H\&E) [1, 2]. Do standardowej oceny nie są zalecane metody immunohistochemiczne (IHC) i molekularne, np. reakcja łańcuchowa polimerazy - PCR (Polimerase Chain Reaction). W piśmiennictwie można spotkać wiele doniesień potwierdzających, że w grupie chorych, gdzie nie stwierdzono obecności MA w badaniu H\&E, to zastosowanie precyzyjniejszych metod (IHC, PCR) pozwala na wykrycie ITC czy MI. Są one nazywane occult metastases, czyli „ukryte” przerzuty. Waewer i współpracownicy w 2011 roku zbadali grupę 3887 chorych, którą wstępnie oceniano jako pNO w badaniach H\&E. Po zastosowaniu dokładniejszych metod (IHC, PCR) u $16 \%$ chorych znaleziono ukryte przerzuty w postaci: ITC $-14 \%, \mathrm{Mi}-4 \%, \mathrm{Ma}-0,4 \%$. Gdyby uwzględnić rozpoznanie tylko MI i MA łącznie, to u 183 chorych $(4,4 \%)$ zaistniałyby podstawy, aby rozpoznać zmiany przerzutowe w węzłach chłonnych [3]. Trwa nadal dyskusja, czy ukryte przerzuty mogą mieć wpływ na przeżycia odległe i czas wolny od choroby. Większość dużych grup badawczych: EORTC (European Organisation for Resarch and Treatment on Cancer), ASCO (American Society of Clinical Oncology), NCCN (National Cancer Center Network), CEEOG (Central and East European Oncology Group) nie poleca metod IHC i PCR do rutynowej oceny węzłów wartowni- 
czych $[2,3,7]$. Być może w najbliższej przyszłości te zalecenia międzynarodowych ekspertów ulegną zmianie.

\section{Czy „dodatnie” wartownicze węzły chłonne stanowią wskazanie do usunięcia pachowych węzłów chłonnych?}

Na wyżej postawione pytanie nie ma jednoznacznej i prostej odpowiedzi. Należy pamiętać, że zgodnie z obowiązującymi algorytmami postępowania rozpoznanie dodatniego węzła wartowniczego może stanowić wskazanie do zastosowania uzupełniającego leczenia systemowego. Ponadto część z tej grupy chorych, ze względu na parametry guza nowotworowego, zostanie zakwalifikowana również do uzupełniającej radioterapii. Ponieważ nie wiemy, czy w pozostałych węzłach chłonnych pachy nie ma pozostawionych innych ognisk przerzutowych, kwalifikujemy chorych do leczenia skojarzonego,"w ciemno”, bez pełnej znajomości zaawansowania RP.

Zgodnie z aktualnym stanem wiedzy onkologicznej w zakresie leczenia RP rozpoznanie ITC w węźle wartowniczym nie stanowi wskazania do usunięcia pachowych węzłów chłonnych [2, 3]. Natomiast rozpoznanie przerzutów w trzech lub większej ilości w węzłów wartowniczych, a szczególnie z towarzyszącym naciekaniem torebki węzła i/lub naczyń, powinno stanowić wskazanie do usunięcia 2 lub 3 pięter pachy w trybie jednoczasowym lub odroczonym [2]. Główna debata, która toczy się obecnie w onkologii, dotyczy podgrupy chorych, u których stwierdzono 1-2 przerzuty do węzłów wartowniczych w postaci MI jak i MA. Odpowiedź na to pytanie próbowały znaleźć trzy duże międzynarodowe grupy badawcze: BCCG (Breast Cancer Cooperative Group), EORTC (European Organisation for Research and Teatment on Cancer), IBCSG (International Breast Cancer Study Group), ACOSOG (American College of Surgeons Oncology Group). Badanie AMAROS (EORTC) nr 10981-22023, o tytule: After Mapping of the Axilla: Radiotherapy or Surgery? dotyczyło 4827 chorych z 35 ośrodków w Europie i było prowadzone w okresie od 2001 do 2010 roku. W badaniu brały udział 3 ośrodki z Polski. Dokładna analiza tego badania nie dała jednoznacznej odpowiedzi na wyżej postawione pytanie [10]. Rekomendacje grupy IBCSG na podstawie badania nr 23-11 zostały przedstawione podczas Konferencji St. Gallen w 2011 roku. Ustalono, że odstąpienie od limfadenektomii u chorych z jednym lub więcej MI w węzłach wartowniczych nie ma wpływu na ogólne przeżycia oraz przeżycia bez objawów wznowy. Badanie dotyczyło chorych na $\mathrm{RP}$, u których stwierdzono MI w węzłach wartowniczych. W ramach leczenia oszczędzającego wszyscy ci chorzy otrzymali radioterapię obejmującą dolne piętro pachy [11]. Badanie ACOSOG nr Z-0011, koordynowane przez Giuliano, wysuwa dalej idące wnioski. Dotyczyło ono chorych, u których stwierdzono jeden lub dwa przerzuty w węzłach chłonnych, określone metodą H\&E. Autorzy tego badania u chorych na RP w stopniu pT1N1M0 (1-2 węzłów wartowniczych) nie zalecają wykonania limfadenektomii, ponieważ ci chorzy otrzymują napromienianie na obszar piersi i dołu pachowego [11]. Badanie Giuliano spotkało się z zasłużoną krytyką. Dotyczyła ona 4 aspektów: kryteria włączenia do badania spełniało zaledwie $50 \%$ chorych (891 spośród 1900); do oceny statystycznej przyjęto zbyt małe liczebności w grupach; wznowy miejscowe w grupie chorych poddanych limfadenektomii, choć nieznamienne statystycznie, były 2-krotnie mniejsze; wielu onkologów w komentarzach do tego badania podawało, że ze względu na nieznany stan pozostałych węzłów pachy trudno było zaplanować optymalne leczenie systemowe [12].

\section{Podsumowanie}

Na podstawie aktualnego stanu wiedzy opartego na dostępnych badań klinicznych można odstąpić od wykonania usunięcia pachowych węzłów chłonnych u chorych na RP z zajętymi węzłami wartowniczymi, jeśli spełnione są następujące warunki:

- Leczenie powinno być przeprowadzone w ośrodkach referencyjnych, które posiadają odpowiednie doświadczenie w technice biopsji węzła wartowniczego i poddają się okresowo zewnętrznej kontroli jakości.

- Zmiany przerzutowe powinny dotyczyć 1-2 węzłów wartowniczych (tzw: mininal sentinel node disease).

- Decyzja o niewykonywaniu limfadenektomii powinna być uzgodniona wspólnie z chorą w zespole wielodyscyplinarnym.

Prof. dr hab. n. med. Janusz Jaśkiewicz

Katedra i Klinika Chirurgii Onkologicznej

Gdański Uniwersytet Medyczny

ul. Smoluchowskiego 17, 80-214 Gdańsk

e-mail:januszj@gumed.edu.pl

\section{Piśmiennictwo}

1. Theriault RL, Carlson RW, Allred C i wsp. Breast cancer version 3.2013: featured updates to the NCCN guidelines. J Natl Compr Canc Netw 2013; 11: 753-761.

2. Kaufmann M, Morrow M, von Minckowitz G i wsp. Locoregiona treatment of primary breast cancer: consensus recomendations from an International Expert Panel. Cancer 2010; 116: 1184-1191.

3. Waewer DL. Ashikaga T, Krag DN i wsp. Effect of occult metastases on survival in node-negative breast cancer. N Engl J Med 2011; 364: 412-419.

4. Giuliano AE, Hunt KK, Ballman KU i wsp. Axillary dissection vs no axillary dissection in women with invasive breast cancer and sentinel node metastasis: a randomized clinical trial. JAMA 2011;305: 569-575.

5. Carter BA, Page DL. Sentinel lymph node histology in breast cancer: minimal disease versus artifact. J Clin Oncol 2006; 24: 1978-1982.

6. Youngson BJ, Liberman L, Rosen PPi wsp. Displacement of carcinomatous epithelium in surgical breast speciment following stereotaxic core biopsy. Am J Cin Pathol 2002; 55: 780-786.

7. Moore KH, Thaler HT, Tan LK i wsp. Immunohistochemically detected tumor cells in sentinel lymph nodes of patients with breast carcinoma: biologic metastases or procedural artifact? Cancer 2004; 100: 929-936. 
8. Milgrom S, Cody H, Tan L i wsp. Characteristic and outcomes of sentinel node-positive breast cancer patients after total mastectomy without axillary-specyfic treatment. Ann Surg Oncol 2012; 19: 3762-3770.

9. Pepels MJ, de Boer P, van Dijck JA i wsp. Regional recurrence in breast cancer patients with sentinel node micrometastases and isolated tumor cells. Ann Surg 2012; 255: 116-121.

10. Galimberti V, Chifu C, Rodriguez Perez S i wsp. Positive axillary sentinel node: is axillary dissection always necessary? Breast 2011; 3: 96-98.
11. Galimberti V, Cole BF, Zurrida S i wsp. Axillary dissection versus no axillary dissection in patients with sentinel-node micrometastases (IBCSG 23-01): a phase 3 randomised controlled trial. Lancet Oncol 2013; 14: 297-305.

12. Giuliano AE, Morrow M, Duggal S i wsp. Should ACOSOG ZOO11 change practice with respect to axillary lymph node dissection for a positive sentinel node biopsy in breast cancer? Clin Exp Metastasis 2012; 29: 687-692 